DOI: $10.1515 / a d m s-2017-0043$

\author{
D. L. Alontseva ${ }^{a^{*}}$, M. B. Abilev ${ }^{b}$ A. M. Zhilkashinova ${ }^{b}$, S. G.Voinarovych ${ }^{c}$, \\ O. N. Kyslytsia ${ }^{c}$, E. Ghassemieh ${ }^{\text {d }}$, A. Russakova ${ }^{a}$, L. Latka ${ }^{e}$ \\ ${ }^{a}$ Department of Instrument Engineering and Technology Process Automation, D. Serikbayev \\ East Kazakhstan State Technical University, Ust-Kamenogorsk, Kazakhstan \\ ${ }^{b}$ S. Amanzholov East Kazakhstan State University, Ust-Kamenogorsk, Kazakhstan, \\ ${ }^{c}$ E.O. Paton Electric Welding Institute, Kiev, Ukraine \\ ${ }^{d}$ Faculty of Engineering and Advanced Manufacturing, University of Sunderland, UK \\ ${ }^{e}$ Department of Materials Science, Strength and Welding, Mechanical Engineering Faculty \\ Wrockaw University of Science and Technology, Poland \\ *dalontseva@mail.ru
}

\title{
OPTIMIZATION OF HYDROXYAPATITE SYNTHESIS AND MICROPLASMA SPRAYING OF POROUS COATINGS ONTO TITANIUM IMPLANTS
}

\begin{abstract}
The paper presents the main results of development and optimization of the synthesis of hydroxyapatite and the application of the micro-plasma spraying technique for biocompatible coatings. The hydroxyapatite synthesis was optimized using the mathematical modelling method. Synthesized hydroxyapatite was studied by IR spectrometry and X-ray diffraction analysis for assessment of the compatibility of the chemical and phase composition to the bone tissue. The $\mathrm{Ca} / \mathrm{P}$ ratio of the obtained hydroxyapatite was 1.65 , which is close to that of bone tissue (1.67). To increase the adhesion strength of the HA coating to the surface of the titanium implant, it was suggested to apply a titanium sublayer to the implant surface. Microplasma spraying (MPS) of biocompatible coatings from titanium wires and synthesized HA powders onto substrates made of medical titanium alloy has been carried out. Microplasmatron MPN-004 is used to obtain the two-layer coatings for titanium implants. The two layer coating includes a sub-layer of a porous titanium coating with a thickness in range from 200 up to $300 \mu \mathrm{m}$ and the porosity level of about $30 \%$, and an upper layer of HA about $100 \mu \mathrm{m}$ thick with $95 \%$ level of HA phases and $93 \%$ level of crystallinity. The pore size varies from 20 to $100 \mu \mathrm{m}$ in both coatings. The paper describes the technology and modes of microplasma deposition of two-layer coatings, including the mode of gas-abrasive treatment of the surface of implants made of titanium alloy before spraying. The synthesized HA powder and the Ti/HA coatings were investigated by optical microscopy and scanning electron microscopy with the energy dispersion analysis and the X-ray diffraction analysis.
\end{abstract}

Keywords: hydroxyapatite (HA), titanium, porous biocompatible coating, microplasma spraying (MPS)

\section{INTRODUCTION}

Currently, endoprosthesis medical practice widely uses metal implants coated with hydroxyapatite (HA), which are characterized by a triple positive effect: increased rate of bone tissue formation, the possibility of formation of a bond with the bone (osseointegration) and decrease in the formation of metal corrosion products [1-4]. Hydroxyapatite (HA) is the 
calcium phosphate mineral $\mathrm{Ca}_{10}\left(\mathrm{PO}_{4}\right)_{6}(\mathrm{OH})_{2}$ of the apatite group. HA is chemically similar to the apatite of the host bone, and is a source of calcium and phosphate for the bone-HA interface [2]. Hydroxyapatite coatings improve osseointegration, at the same time they encapsulate the interface both from wear particles and periprosthetic osteolysis associated with macrophage $[5,6]$. These factors together can significantly reduce the duration of implantation of the endoprosthesis, provide a reliable connection with the bone and increase the reliability of implants. [1-6].

Synthetic and natural HA are different in terms of their microstructure arrangements. The HA contained in the bone is represented by lamellar microcrystals dimensioned about (1.5-3.5 $\mathrm{nm}) \times(5.0-10.0 \mathrm{~nm}) \times(40.0-50.0 \mathrm{~nm})$. The cortical bone consists of HA crystals $(70 \mathrm{wt} . \%-$ inorganic component) associated by collagen fibers (30 wt.\% - organic component of bone tissue, or bone matrix) [7-9]. In addition to these substances in the bone tissue there are small amounts of other organic compounds (non-collagen proteins, polysaccharides, lipids). The varieties of synthetic HA - from fine powders to non-porous ceramics - do not exactly reproduce the structure of HA bone natural crystals. However they are engaged in the metabolic processes of a living body and are processed by the body with different intensities depending on the HA structure, chemical composition, and specific surface area. Numerous studies in animals and humans have shown that HA is non-toxic, does not exhibit allergic and inflammatory reactions $[2,6,10,11]$. Therefore, development of new and affordable methods for the synthesis of fine crystalline hydroxyapatite for the use as bioactive coatings on titanium from composite materials is of significance. Synthesis of artificial HA is carried out, mainly, by precipitation from aqueous solutions of calcium salts with ammonium hydrogen phosphate [8,9]. According to this method, amorphous precipitates of hydroxyapatite of variable composition are agglomerated during the drying and sintering process. Therefore it requires additional milling process to obtain various particle size distributions. Therefore, the use of soluble calcium compounds to produce highly dispersed powders is preferred. This method implements a well-known "bottom-up" approach to the creation of a dispersed system [11]. In this method, with the presence of sucrose, the solubility of calcium hydroxide increases due to the formation of soluble compounds. Organic substances, adsorbed on the surface of the formed inorganic crystals, block their growth and ensure the formation of a crystalline powder [7].

Preparation of synthetic HA meeting the basic requirements for using in various proposes is a multistage process. The synthesis parameters need to be controlled in order to produce HA of high quality. On the other hand, experimental optimization of the synthesis process is very complex, time and labor consuming study. In this light, search for the express optimization methods becomes more topical. Among such methods, mathematical modeling of the synthesis process is of interest due to the absence of need to carry out complex studies. Since the synthesis of HA is affected by many controlled factors (e.g. synthesis time, aging time, $\mathrm{pH}$, synthesis temperature, concentrations of reagents, etc.), the methods of mathematical optimization are a great choice for improving the process of HA synthesize. To apply the mathematical modeling, the initial data is collected by carrying out preliminary studies on the influence of each factor separately. Then, the obtained dependencies are processed by regression analysis method, and the generalized dependence is derived. The final dependence shows how all the studied factors affect the efficiency of the process.

To ensure a lasting and durable fixation of the implant to the bone, it is essential that the coatings satisfy certain requirements with respect to the following features:

- Chemical and phase composition of the coatings;

- The thickness and surface roughness of the coating;

- Mechanical properties of coatings; 
- Porosity of the coatings;

- Adhesion to the implant.

There are various methods of applying HA coatings to metal, including titanium implants such as: magnetron sputtering, joint electron beam, ion-stimulated precipitation, laser ablation, chemical vapor deposition, electrophoretic deposition, sol-gel, biomimetic methods [13-21]. One of the main commercially viable methods of producing biocompatible coatings is plasma spraying $[11,16,20,21]$. The porous structure of the coating, developed by plasma spraying method, promotes the effective intergrowth of bone tissue into the pores of the implant. This in turn contributes to its reliable fixation in the bone. It has been shown by previous researches that the biocompatible coatings should have macro-pores not smaller than $100 \mu \mathrm{m}$ and micro-pores not larger than $20 \mu \mathrm{m}$ and an overall porosity range of not less than 25 vol.\% [11,21]. Sintered HA can form firm bonds with living bone with little degradation of the HA layer. The coatings developed are generally lower than $100 \mu \mathrm{m}$ in their thickness. This is due to the restrictions the process imposes to achieve a good quality spray coating. However the thin coating could result in suboptimal fatigue life of the coating. Therefore an optimal thickness needs to be identified and achieved. The experiments with animal models demonstrated the similarity of the shear strength of HA plasma deposited titanium alloy implants and the shear strength of cortical bone [11]. Evidently, the bone-implant interface and HA are bonded both chemically and biologically. This claim is based on the observation that osteoid is formed by osteoblasts directly on the HA coating surface.

The disadvantage of hydroxyapatite plasma sprayed coatings is usually a large content of the volume fraction of the amorphous phase and also the possibility of their partial decomposition. This is due to the conditions of heating of the HA particles using gases with high thermal conductivity (a mixture of $\mathrm{Ar}+\mathrm{H}_{2}, \mathrm{Ar}+\mathrm{He}$ ), and solidification of the melted HA particles on the substrate surface [22]. The chemical composition of the final coating is dependent on the thermal decomposition occurring during spraying. The high temperatures experienced by HA powder particles in the plasma spraying process lead to the dehydroxylation and decomposition of the particles. At temperatures of above $800{ }^{\circ} \mathrm{C}$ dehydroxylation of HA occurs. Whilst above $1050{ }^{\circ} \mathrm{C}$ HA decomposes to tricalcium phosphate $\beta$-TCP $-\mathrm{Ca}_{3}\left(\mathrm{PO}_{4}\right)_{2}$ and tetracalcium phosphate TTCP-Ca $\left(\mathrm{PO}_{4}\right)_{2} \mathrm{O}$ and above 1120 ${ }^{\circ} \mathrm{C} \beta$-TCP is converted to $\alpha$-tricalcium phosphate $-\mathrm{Ca}_{3}\left(\mathrm{PO}_{4}\right)_{2}$. [23-25]. Thus the resulted coating phase composition depends on the thermal history of the powder particles. The higher the plasma jet temperature and the longer the exposure of the particles to plasma, the greater the degree of phase transformation. According to the ISO standard specification (ISO 137792:2000) the maximum allowable level of non-HA phases in a HA coating is 5\% [26]. Considering the differences in dissolution properties between the different calcium phosphate phases, the phase purity of HA coatings should be thoroughly controlled.

The phase composition of the coating (degree of crystallinity) largely affects the process of osseointegration [27]. The amorphous phase of HA has a higher rate of dissolution, which reduces the recovery time of the patient, but at the same time some reduction of the reliability of fixation of the endoprosthesis in the bone is also possible. Thus, increased crystallinity appears to slow resorption of HA, which leads to a slight decrease of bone ingrowth [28], yet provides reliable fixation of the implant in the bone $[2,27]$. The bioresorption of HA coatings as well as the optimal value for coating roughness is still a matter of controversy. The HA coating surface roughness affects osteoblast cell bonding and, consequently, bone growth on the coating after implant placement. Osteoblasts bonding and proliferation are better on rough surfaces [29]. High degree of surface roughness results in a greater coating dissolution rate. Therefore HA coatings go through variable resorption prescribed by a number of biological, mechanical, and chemical factors determined by their anatomical location, the composition 
and physico-chemical properties, etc. [28-32].

E. O. Paton Electric Welding Institute (EWI) has developed a method and equipment for microplasma spraying (MPS), which allows applying ceramic coatings using a laminar jet of argon plasma [33]. Low thermal conductivity of argon reduces the intensity of heating of the particles, thus reducing the temperature gradient in their cross section. This substantially helps avoiding overheating of HA melt and the formation of toxic products of its decomposition $(\mathrm{CaO})$ through the spraying process. Low velocities of HA particles under laminar flow conditions lead to the formation of coatings from particles with a lower degree of deformation and, accordingly, a lower rate of their quenching on the substrate. Consequently this provides a high content of the crystalline phase (up to $98 \%$ ) [34]. Thus, the use of microplasma spraying HA coatings provides advantages in the formation of coatings with the desired structural and phase composition. In addition, it is possible to form coatings with controlled porosity, by varying the parameters of spraying, such as the powder feed rate, the speed of movement of the source along the sprayed surface, the spray distance, and the current [35-38].

According to the current ISO standard specification (ISO 13779-2: 2000) [26] one of the main requirements for the quality of hydroxyapatite biocompatible coatings, in addition to their phase composition and porosity, is the adhesion strength of the coating to the endoprosthesis surface. The adhesion strength higher than $15 \mathrm{MPa}$ is required. However, the adhesion of hydroxyapatite coatings to the titanium or titanium alloy implants presents significant challenges due to inherent differences in physical and mechanical properties. In such a compound undesirable residual stresses may occur due to the difference in thermal expansion coefficients, which lead to both cracks in the coating and a decrease in the strength of adhesion of the coating to the substrate. The strength of the bonding of the coating to the implant is also affected by the surface roughness of the coating, and also the size and shape of the sprayed particles [39]. To increase the adhesion strength of the coating to the implant surface, the specialists from the E. O. Paton EWI have developed the technology for microplasma spraying of two-layer biocermet (bio ceramics-metal) coating ( $\mathrm{Ti}+\mathrm{HA}$ ) on the surface of the implant. In this technique, relatively dense HA coating is successfully deposited on a porous titanium sublayer. Microplasma sprayed porous titanium sublayer with developed surface relief has low thermal conductivity in comparison with the equivalent dense material. Due to the surface roughness, the temperature at the microelevations under the sprayed particle can significantly exceed the temperature at the points of its contact with the smooth surface. At the same time, heat accumulation increases at the coating boundary with the sublayer material. Consequently, the chemical interaction of hydroxyapatite with the oxide film on the sprayed titanium sublayer is activated and the adhesion strength of the coating with the implant increases. The bond strength in this case is provided by chemical covalent bindings in the produced compounds such as $\mathrm{CaTiO}_{3}$. Such processes of interaction activation at the tops of micro elevations are important at low rates of collision of sprayed particles with the substrate, which is typical for MPS. In addition, the sprayed titanium sublayer with developed surface relief has a rather larger specific contact area with HA coating compared to a smooth surface, which also increases the adhesion strength [23].

It should also be noted that when placing an implant with a titanium sublayer with a developed surface relief and HA-coating into the bone, the outer layer of hydroxyapatite will provide a biological bond with the bone, while additional mechanical fixation will be achieved by bone ingrowth into the porous structure of the titanium sublayer. We have described the modes of microplasma spraying biocermet two-layer coatings on different substrates in our previous publications [35-37]. We also have explained how the proposed system of coating can result in achieving the adhesion recommended by ISO 137794:2002(E). Before coating deposition the substrates were subjected to gas-abrasive treatment, then they were coated with porous titanium wire coating (pore size up to150 $\mu \mathrm{m}$ ), and HA 
powder (powder size from 40 to $90 \mu \mathrm{m}$ ). Our studies showed the adhesion strength of twolayer biocermet coatings with a titanium alloy base to be $24.2 \pm 0.85 \mathrm{MPa}$. This is well beyond the requirement of the ISO 13779-4:2002(E) which is $15 \mathrm{MPa}$.

Currently, D. Serikbayev East Kazakhstan State Technical University along with specialists from E. O. Paton EWI are running combined activities on developing compositions and technologies of deposition of biocompatible coatings on endoprostheses using the medical alloy produced in Kazakhstan by means of microplasma spraying [40, 41]. In order to form a $\mathrm{Ti} / \mathrm{HA}$ two-layer porous coating on the implant surface by microplasma spraying several stages of activities needs to be completed. It is necessary to synthesize the hydroxyapatite powder of the desired composition with particles of a certain size and shape, suitable for MPS. The other stage of process is to prepare the implant surface for spraying with desired roughness. Then the modes of microplasma deposition of both titanium wire and HA powder should be selected. Each of these processes requires further development and optimization. For example the selection of modes of gas-abrasive surface treatment, modes of microplasma deposition of wire and powder and optimization of synthesis of hydroxyapatite powder are amongst this combined and multifaceted research effort.

Here we focused only on the process of synthesis of HA with the desired chemical composition and powder particle size suitable for MPS on titanium alloy endoprostheses. Also we showed the two-layer titanium/hydroxyapatite coating obtained as a result of MPS, which has satisfactory porosity, with the desired phase composition and degree of HA crystallinity.

\section{EXPERIMENTAL}

Samples of hydroxyapatite were synthesized by chemical precipitation. The following components of p.a. grade were used as precursors: calcium nitrate, ammonium hydrophosphate, and ammonia solution as a precipitant. $\left(\mathrm{NH}_{4}\right)_{2} \mathrm{HPO}_{4}$ solution was slowly introduced into $\mathrm{Ca}\left(\mathrm{NO}_{3}\right)_{2}$ solution with constant stirring; an ammonia solution was introduced to obtain a target $\mathrm{pH}$ of the medium. The $\mathrm{pH}$ values were controlled with $\mathrm{pH}-150 \mathrm{MI} \mathrm{pH}-$ meter (Izmeritel'naya tekhnika, Russia). After aging, the precipitate was filtered off, washed with hot distilled water, dried at a temperature of $(105 \pm 5){ }^{\circ} \mathrm{C}$, heated for 1 hour at the temperature of $250{ }^{\circ} \mathrm{C}$ to remove residual ammonium nitrate. The conditions for the synthesis of the hydroxyapatite (synthesis time, aging time, $\mathrm{pH}$, synthesis temperature, concentration of calcium nitrate, concentration of ammonium hydrogen phosphate) are shown in Table 1. To evaluate the effect of each of factor, studies were carried out using the six-factorial design of the experiment. The total number of samples was 36. Synthesis time was varied from 2 to 60 minutes, aging time -16 to 36 hours, $\mathrm{pH}$ of the medium - from 5 to 13 , the synthesis temperature - from 30 to $80^{\circ} \mathrm{C}$, the concentration of calcium nitrate - from 0.1 to $2 \mathrm{~mol} / \mathrm{L}$, the concentration of ammonium hydrophosphate - from 0.06 to $1.2 \mathrm{~mol} / \mathrm{L}$.

The process of hydroxyapatite synthesis using calcium nitrate, ammonium hydrogen phosphate and ammonia solution as precursors proceeds in accordance with the reaction (1).

$$
10 \mathrm{Ca}\left(\mathrm{NO}_{3}\right)_{2}+6\left(\mathrm{NH}_{4}\right)_{2} \mathrm{HPO}_{4}+8 \mathrm{NH}_{4} \mathrm{OH} \rightarrow \mathrm{Ca}_{10}\left(\mathrm{PO}_{4}\right)_{6}(\mathrm{OH})_{2}+20 \mathrm{NH}_{4} \mathrm{NO}_{3}+6 \mathrm{H}_{2} \mathrm{O}
$$


Table 1. Levels of factors when optimizing the parameters of hydroxyapatite synthesis

\begin{tabular}{clcccccc}
\hline \multirow{2}{*}{$\begin{array}{c}\text { Factor } \\
\text { number }\end{array}$} & \multicolumn{1}{c}{ Factor } & \multicolumn{7}{c}{ Levels } \\
\cline { 2 - 7 } & & 1 & 2 & 3 & 4 & 5 & 6 \\
\hline 1 & Synthesis time, min & 2 & 10 & 30 & 40 & 50 & 60 \\
2 & Aging time, h & 16 & 20 & 24 & 28 & 32 & 36 \\
3 & pH & 5 & 7 & 9 & 11 & 12 & 13 \\
4 & Synthesis temperature, ${ }^{\circ} \mathrm{C}$ & 30 & 40 & 50 & 60 & 70 & 80 \\
5 & Concentration of calcium nitrate, $\mathrm{M}$ & 0.1 & 0.2 & 0.5 & 1 & 1.5 & 2 \\
6 & Ammonium hydrogen phosphate & 0.06 & 0.1 & 0.3 & 0.6 & 0.9 & 1.2 \\
\hline
\end{tabular}

The chemical compositions of the synthesized samples of hydroxyapatite were determined after dissolving a sample of hydroxyapatite in the solution of concentrated nitric acid. The calcium content was determined by the atomic absorption method using MGA-915 spectrometer with electrothermal atomization (Lumakhrom, Russia); the phosphorus content was assessed - by the photometric method based on the light absorption of the complex phosphorus compound with hydrazine sulfate. The optical density was measured using PA5400 UF spectrophotometer (Ecokhrom, Russia) in cuvettes with the absorbing layer thickness of $10 \mathrm{~mm}$ at the wavelength of $830 \mathrm{~nm}$. The quality of synthesized hydroxyapatite samples was evaluated by studying the chemical composition $(\mathrm{Ca} / \mathrm{P}$ stoichiometric composition), phase composition, and solubility. Statistical processing of the results was carried out based on the ratio of calcium to phosphorus. The obtained results were compared with the results of biological hydroxyapatite tests (sample O-1). Sample O-1 was obtained from cattle bone sludge (deproteinised and defatted bone pulp) according to [42]. The IR spectrum of the biological sample is shown in Fig. 1.

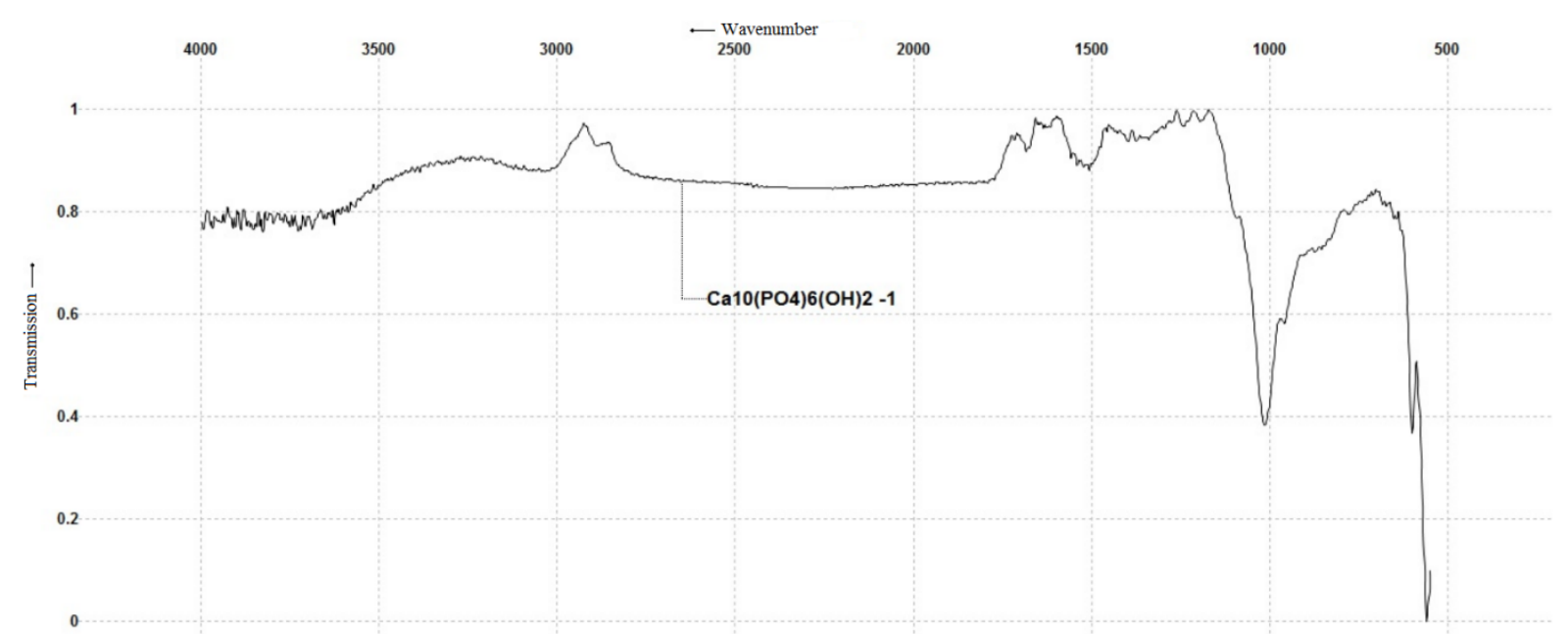

Fig. 1. The IR spectrum of biological hydroxyapatite (sample O-1)

Determination of the composition of functional groups in the sample, detection of distortion in the crystal structure of hydroxyapatite was performed by IR spectroscopy on FT801 FT-IR spectrometer in the spectral range of $350-7800 \mathrm{~cm}^{-1}(\mathrm{KBr})$ with an uncooled pyroelectric photodetector at the signal-to-noise ratio greater than 25,000:1. The identification 
of the absorption bands was made according to the tables of characteristic frequencies based on the literature and reference data.

To assess the solubility of hydroxyapatite, the total concentration of calcium ions in the physiological solution $(\omega(\mathrm{NaCl})=0.9 \%)$ was determined at $20^{\circ} \mathrm{C}$ and $37{ }^{\circ} \mathrm{C}$, in which the samples were held for 7 days to achieve saturation with respect to the solid phase. Atomic absorption with electrothermal atomization was used as an analytical method (MGA-915 spectrometer). The content of calcium ions was evaluated by examining three samples.

Before the use as coating, the obtained HA powder was heated to the temperature of 800 ${ }^{\circ} \mathrm{C}$ in SNOL 7,2/1100 furnace for 1 hour. The powder was wiped through a sieve in a wet state to obtain granules of the size from 50 to $100 \mu \mathrm{m}$. The dried granules of the HA powder were subjected to additional milling in order to avoid agglomeration of the particles.

Grade 5 ELI titanium medical alloy samples were used as substrates for microplasma spraying. A wire of commercially pure titanium of $0.3 \mathrm{~mm}$ in diameter was used to apply the titanium coatings. Table 3 and Table 2 show the standard composition of the substrate and wire materials respectively. These are also checked in our labs using the energy-dispersive analysis.

Table 2. Chemical composition of Grade 5 ELI titanium medical alloy [ISO 5832-3/ASTM F 136]

\begin{tabular}{|c|c|c|c|c|c|c|c|}
\hline \multicolumn{7}{|c|}{ wt. \% of element } \\
\hline $\mathrm{Fe}$ & $\mathrm{N}$ & $\mathrm{O}$ & $\mathrm{Al}$ & $\mathrm{C}$ & $\mathrm{V}$ & $\mathrm{H}$ & $\mathrm{Ti}$ \\
\hline $0.25-0.40$ & $<0.05$ & $0.13-0.20$ & $5.50-6.75$ & $<0.08$ & $3.50-4.50$ & $<0.015$ & balance \\
\hline
\end{tabular}

Table 3. Chemical composition of BT1-00 commercially pure titanium [GOST 19807-91]

\begin{tabular}{|c|c|c|c|c|c|c|c|}
\hline \multicolumn{7}{|c|}{ wt. \% of element } \\
\hline $\mathrm{Al}$ & $\mathrm{Fe}$ & $\mathrm{Si}$ & $\mathrm{C}$ & $\mathrm{N}$ & $\mathrm{H}$ & $\mathrm{O}$ & $\mathrm{Ti}$ \\
\hline$<0.3$ & $<0.15$ & $<0.08$ & $<0.05$ & $<0.03$ & $<0.003$ & $<0.12$ & balance \\
\hline
\end{tabular}

The surfaces of the sprayed implants have been degreased with acetone and ultrasonically cleaned. To ensure proper adhesion of the coatings, it is important to pretreat the substrates surfaces to increase the roughness by gas treatment. Gas-abrasive treatment is required for surface activation. Since the activity of the base reduces rapidly due to chemical gases adsorption from the atmosphere and oxidation, the time between gas-abrasive surface preparation and coating should not exceed 2 hours. The implants have been stored in a hermetically sealed container (eg. in exsiccator) between the periods of treatments. Gasabrasive surface treatment has been carried out on the titanium alloys according to the mode reported in Table 4. Electrocorundum of normal grade 12Ahas been used as abrasive material in accordance with GOST 2MT 793-80 standard. To clean the surface of implanted particles of abrasive material, implants have been subjected to ultrasonic cleaning in a medical alcohol for 15 minutes.

The surface roughnesses of the substrates and coatings $(\mu \mathrm{m})$ were measured with a profilometer model 130 (Russia) according to GOST 25142-82.

The measured surface roughness of the titanium alloy implant (substrate) after gasabrasive treatment was on average $\mathrm{Ra}=1.00 \pm 0.40 \mu \mathrm{m}$.

Microplasma deposition of coatings from titanium wires and HA-powders onto substrates made of medical titanium alloy was applied with the use of microplasmatron MPN-004 manufactured by E.O. Paton Electric Welding Institute (Kiev, Ukraine). The microplasmatron was fixed on the arm of the robot manipulator Kawasaki RS-010LA (Kawasaki Robotics, Japan). It was enabled to move horizontally along a computed trajectory at the speed of 50 
$\mathrm{mm} / \mathrm{s}$. When selecting the thickness of applied layers (about $200 \mu \mathrm{m}$ for Ti-layer and $100 \mu \mathrm{m}$ for HA-layer) it was taken into account that in case of microplasma application of biocompatible coatings with a thickness of less than $200 \mu \mathrm{m}$, a large pore size of about 150 $\mu \mathrm{m}$ can result in formation of through-thickness porosity and cause an adverse contact and interaction of the implant metal with the body environment. The modes for applying twolayer coatings from Ti-wire and HA-powders to titanium alloy substrates are presented in Table 5.

Table 4. The mode of gas-abrasive treatment for implants from titanium and titanium alloys

\begin{tabular}{ll}
\hline \multicolumn{1}{c}{ The parameters of gas-abrasive treatment } & Setting parameters \\
\hline Fraction of abrasive, $\mathrm{mm}$ & $0.6 \ldots 0.8$ \\
Pressure of compressed air, MPa & $0.4 \ldots 0.6$ \\
Distance from the nozzle cut to the treated surface, $\mathrm{mm}$ & $100 \ldots 120$ \\
Incident angle of an abrasive jet on the surface to be treated, degrees & $60 \ldots 90$ \\
Linear speed of pistol moving, $\mathrm{mm} / \mathrm{min}$ & $250 \ldots 600$ \\
\hline
\end{tabular}

Table 5. Modes of microplasma spraying of titanium and HA coatings on a substrate of a titanium alloy

\begin{tabular}{ccc}
\hline Spray parameters & \multicolumn{2}{c}{ Setting parameters } \\
\cline { 2 - 3 } & $\begin{array}{c}1^{\text {st }} \text { layer from Ti } \\
\text { wire }\end{array}$ & $\begin{array}{c}2^{\text {nd }} \text { layer from } \\
\text { HA powders }\end{array}$ \\
\hline Primary Gas & \multicolumn{2}{c}{$\begin{array}{c}\text { Argon } \\
\text { Argon }\end{array}$} \\
Powder Carrier Gas & \multicolumn{2}{c}{ Argon } \\
Current & $16 \mathrm{~A}$ & $45 \mathrm{~A}$ \\
Carrier Gas Flow Rate & $2.33 \mathrm{SLPM}$ & $1.00 \mathrm{SLPM}$ \\
(standard liter per minute, SLPM) & & \\
Spray Distance & $40 \mathrm{~mm}$ & $160 \mathrm{~mm}$ \\
Feed Rate of materials & $3 \mathrm{~m} / \mathrm{min}$ & $0.4 \mathrm{~g} / \mathrm{min}$ \\
\hline
\end{tabular}

To evaluate the porosity of the coatings, the images being obtained by optical microscope Olympus BX-51 (Japan) and by scanning electron microscope JSM-6390LV (JEOL, Japan) were processed using $\mathrm{ZAF} / \mathrm{PB}$, Micro Capture, Atlas computer-aided programs. The measurements were carried out on the polished cross section of the coatings as per ASTM B276 standard [43]. The morphologies and chemical composition of the powder, coatings and substrates were analyzed with a scanning electron microscopy by JSM-6390LV (JEOL, Japan) with the detachable device of the energy dispersive spectroscopy analysis INCA ENERGY (Oxford Instruments, UK).

The crystallinity of the powder and coatings was measured by X'Pert PRO diffractometer (PANalytical, the Netherlands). Interpretation of the X-ray diffraction patterns was carried out using Rietveld method and licensed data of the PCF DFWIN (140,000 connections), the ASTM card file and Diffracts Plus software. The \% crystallinity of the HA powder was calculated using the area of crystalline peaks in the region 20 to $40^{\circ} 2 \theta$ and the area of the amorphous diffuse background in this region.

No clinical tests on humans or animals have been carried out. 


\section{RESULTS AND DISCUSSION}

\section{Optimization of synthesis process}

In order to obtain HA particles in the range of $40-90 \mu \mathrm{m}$ before sieving, it is necessary to synthesize a sample of hydroxyapatite under the certain conditions. These conditions were determined using mathematical modeling. These conditions were determined using mathematical modeling, namely the method of six factorial design of experiment indicated earlier in the paper (EXPERIMENTAL PART). The results are shown in Table 1. Since the aging time of the precipitate has a significant effect on the phase composition and particle size of hydroxyapatite, it was expedient to calculate the optimal precipitate aging time at constant values of the remaining factors on the basis of regression analysis and the generalized Protodyakonov equation [44]. The regression equations were derived after averaging the experimental data and the selection of approximating functions. These equations described by quadratic parabola functions are shown in Table 6. Graphic dependencies of the stoichiometric composition of synthesized hydroxyapatite samples are shown in Fig. 2.

Table 6. The correlation coefficient $R$ and its significance $t R$ for particular functions of the dependence of the Ca/P ratio on the levels of variable parameters

\begin{tabular}{ccccc}
\hline $\begin{array}{c}\text { Factor } \\
\text { number }\end{array}$ & Equation & $\mathrm{R}$ & $\mathrm{t}_{\mathrm{R}}$ & Significance \\
\hline 1 & $Y_{1}=0.922+9.39 \cdot 10^{-3} x_{1}-1.69 \cdot 10^{-4} x_{1}^{2}$ & 0.9697 & 5.61 & Significant \\
2 & $Y_{2}=0.238+3.33 \cdot 10^{-2} x_{2}-3.94 \cdot 10^{-4} x_{2}^{2}$ & 0.9963 & 16.34 & Significant \\
3 & $Y_{3}=0.281+0.155 x_{3}-9.56 \cdot 10^{-3} x_{3}^{2}$ & 0.9818 & 7.31 & Significant \\
4 & $Y_{4}=-0.259+4.71 \cdot 10^{-2} x_{4}-4.57 \cdot 10^{-4} x_{4}^{2}$ & 0.9992 & 34.39 & Significant \\
5 & $Y_{5}=0.517+0.898 x_{5}-0.391 x_{5}^{2}$ & 0.9793 & 6.84 & Significant \\
6 & $Y_{6}=0.546+1.300 x_{6}-0.909 x_{6}^{2}$ & 0.9692 & 5.57 & Significant \\
\hline
\end{tabular}

Table 6 shows that all the studied factors have a significant effect on the stoichiometric composition of synthesized hydroxyapatite samples in the studied ranges (Table 1). In this study, we use the least squares regression analysis to process the dependencies, and generalized Protodyakonov equation to evaluate the effect of each studied factor.

Based on the obtained results, the generalized Protodyakonov equation was derived, taking into account the effects of the six factors in the studied ranges on the stoichiometric composition of synthesized hydroxyapatite (2).

$$
\begin{aligned}
& Y_{\Pi}=\left(\left(-\frac{1.69 x_{1}^{2}}{10^{4}}+\frac{9.39 x_{1}}{10^{3}}+0.922\right) \cdot\left(-\frac{3.94 x_{2}^{2}}{10^{4}}+\frac{3.33 x_{2}}{10^{2}}+0.238\right) .\right. \\
& \left(-\frac{9.56 x_{3}^{2}}{10^{3}}+0.155 x_{3}+0.281\right) \cdot\left(-\frac{4.57 x_{4}^{2}}{10^{4}}+\frac{4.71 x_{4}}{10^{2}}-0.259\right) \cdot \\
& \left.\left(-0.391 x_{5}^{2}+0.898 x_{5}+0.517\right) \cdot\left(-0.909 x_{6}^{2}+1.300 x_{6}+0.546\right)\right) / 0.679^{5}
\end{aligned}
$$



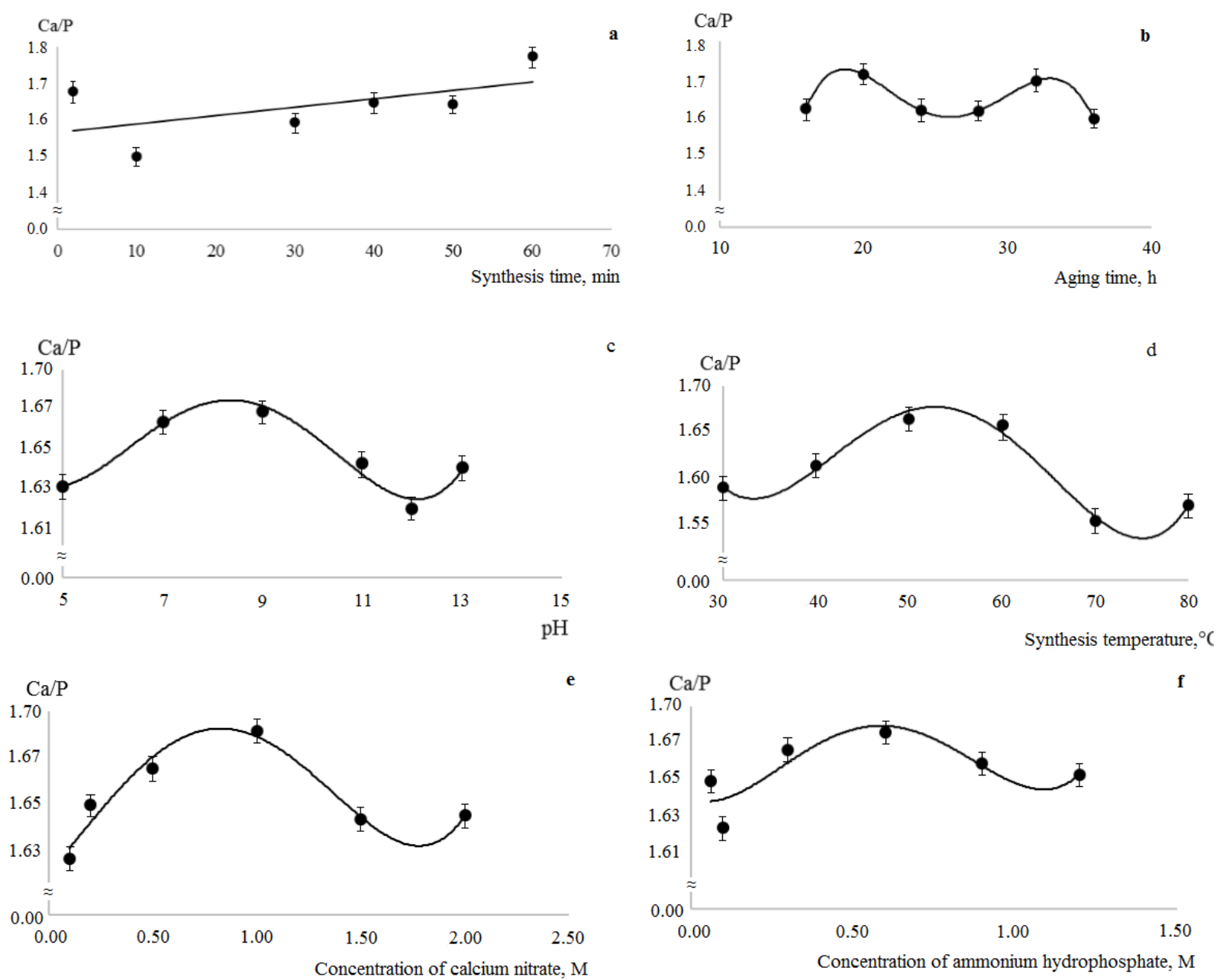

Fig. 2. Influence of selected factors on the stoichiometric composition of synthesized hydroxyapatite a - synthesis time, min; b - aging time, min; $\mathrm{c}$ - $\mathrm{pH}$; $\mathrm{d}$ - synthesis temperature, ${ }^{\circ} \mathrm{C}$;

e - concentration of calcium nitrate, mol/L; $f$ - concentration of ammonium hydrophosphate, $\mathrm{mol} / \mathrm{L}$

The significance of the correlation coefficient of the generalized function was 2.41 . Exceeding the $t_{R}$ of the critical value of the Student's coefficient (2.28) indicates the adequacy of the derived generalized Protodyakonov equation. Based on the regression equations for all six factors studied and the generalized Protodyakonov equation, the optimal value of the aging time of the hydroxyapatite precipitate $\left(\mathrm{Y}_{\mathrm{n}}\right)$ was calculated, which was 32 hours. The IR spectrum of the hydroxyapatite (O-3) sample synthesized using optimized parameters is shown in Fig. 3. The spectrum is characterized by the presence of $\mathrm{OH}$-groups bands: $\mathrm{OH}-$ valence vibrations in the region of $3570-3770 \mathrm{~cm}^{-1}$ and vibrations of $\mathrm{OH}$-groups participating in the formation of the hydrogen bond in the region of $3380-3570 \mathrm{~cm}^{-1}$. Oscillations in the range $1035-1185 \mathrm{~cm}^{-1}$ refer to the valence antisymmetric and symmetric vibrations of the P-O bonds in the phosphate group.

To increase the rate of the hydroxyapatite synthesis, the aging process was assisted by ultrasonic action (Sapphire 12.0 TTC, Russia, power of the ultrasonic generator $60 \%$ ). Due to the ultrasonic treatment the aging time was reduced to 16 hours.

An analysis of the experimental results indicates that the optimal conditions for obtaining the HA powder with particle size in the range of the $40-90 \mu \mathrm{m}$ are as follows: synthesis time $60 \mathrm{~min}, \mathrm{pH} 9$, synthesis temperature $-50{ }^{\circ} \mathrm{C}$, concentration of calcium nitrate $-1 \mathrm{~mol} / \mathrm{L}$, concentration of ammonium hydrophosphate $-0.6 \mathrm{~mol} / \mathrm{L}$. The aging time is 16 hours under the ultrasonic treatment. The IR spectrum of the obtained sample (Fig.3) indicates the 
presence of one phase of hydroxyapatite. This it is closely matched to the IR spectrum of biological hydroxyapatite (Fig.1). According to the results of elemental analysis, the ratio of calcium to phosphorus was 1.65 , which indicates a high stoichiometry of the sample.

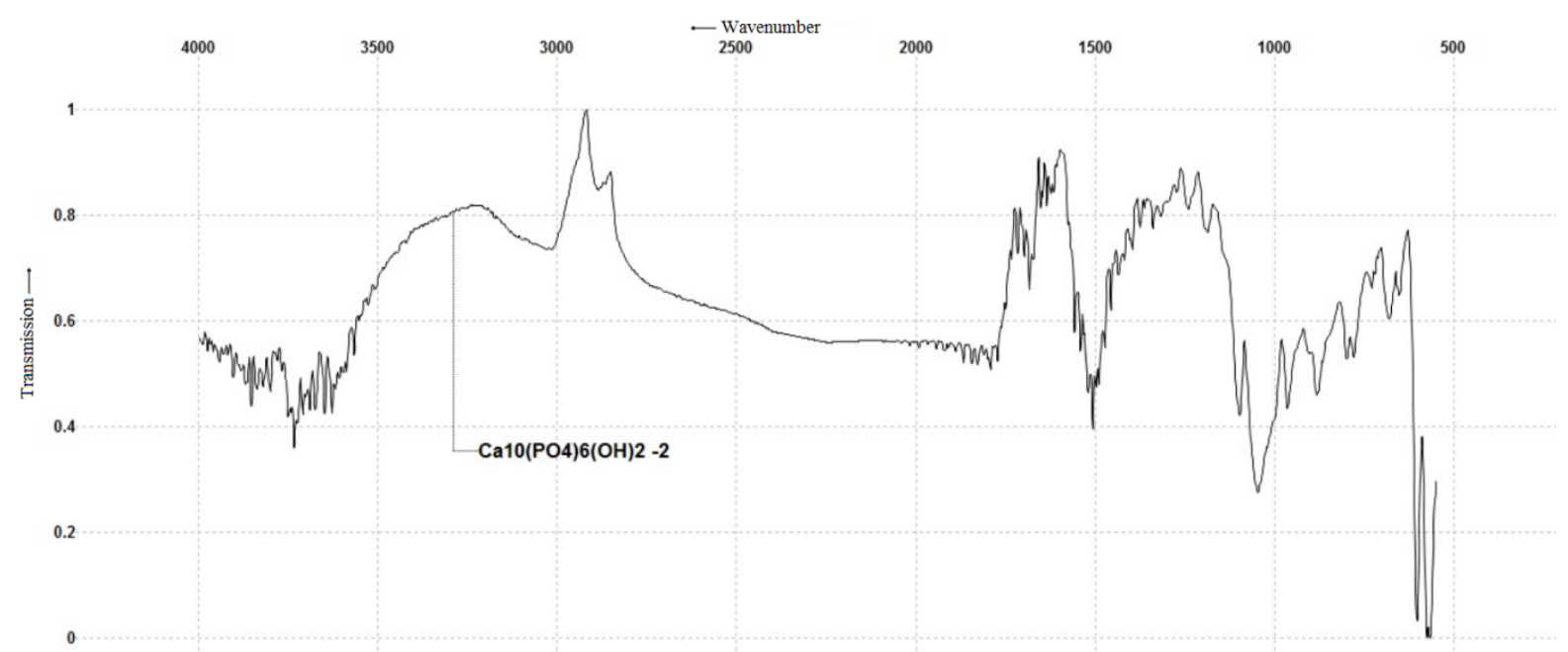

Fig. 3. The IR spectrum of synthesized hydroxyapatite (sample O-3)

To complete the crystallization of synthesized hydroxyapatite, the sample was calcined. The heat treatment was carried out for 1 hour at the temperature of $800{ }^{\circ} \mathrm{C}$. The crystallinity of the obtained hydroxyapatite was at the level of $95.67 \%$.

\section{Microplasma spraying}

HA powder was used as a sprayed coating material; it had a splinter form with a large size difference of the axes of the particles (Fig 4). Before MPS, the dried and milled HA powder was sieved through the sieves with mesh diameters $40 \mu \mathrm{m}$ and $90 \mu \mathrm{m}$, to obtain only fractions with desired sizes. According to our previous studies, the particle size of the HA powder for MPS should be in the range from 40 to $90 \mu \mathrm{m}$ [40, 41]. XRD analysis confirmed that the phase composition of the powder was fully crystalline $\mathrm{Ca}_{10}\left(\mathrm{PO}_{4}\right)_{6}(\mathrm{OH})_{2}$ with the ratio $\mathrm{Ca} / \mathrm{P}$ of 1.65. The modes for MPS of two-layer coatings from Ti-wire and HA-powders to titanium alloy substrates are presented in Table 5. The images of microstructure of microplasma sprayed under specified modes two-layers Ti/HA coatings are presented in Fig.5.
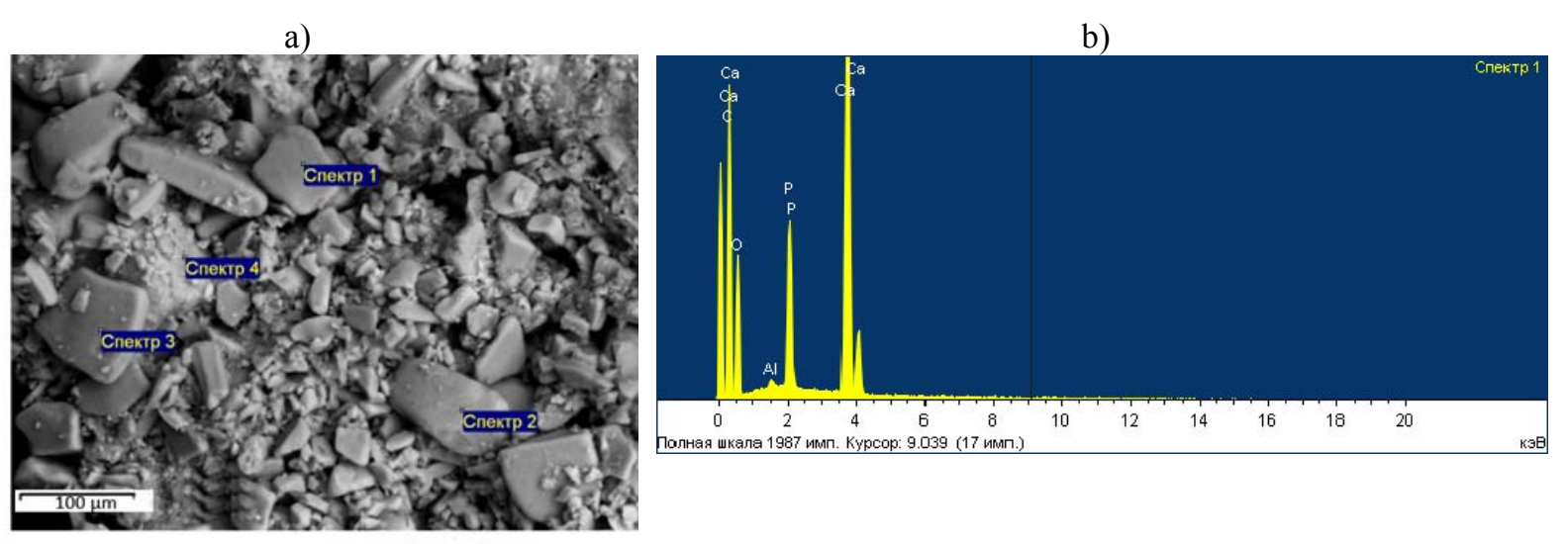

Fig. 4. SEM image of HA particles (a) with EDX-spectrum (b)

a) 

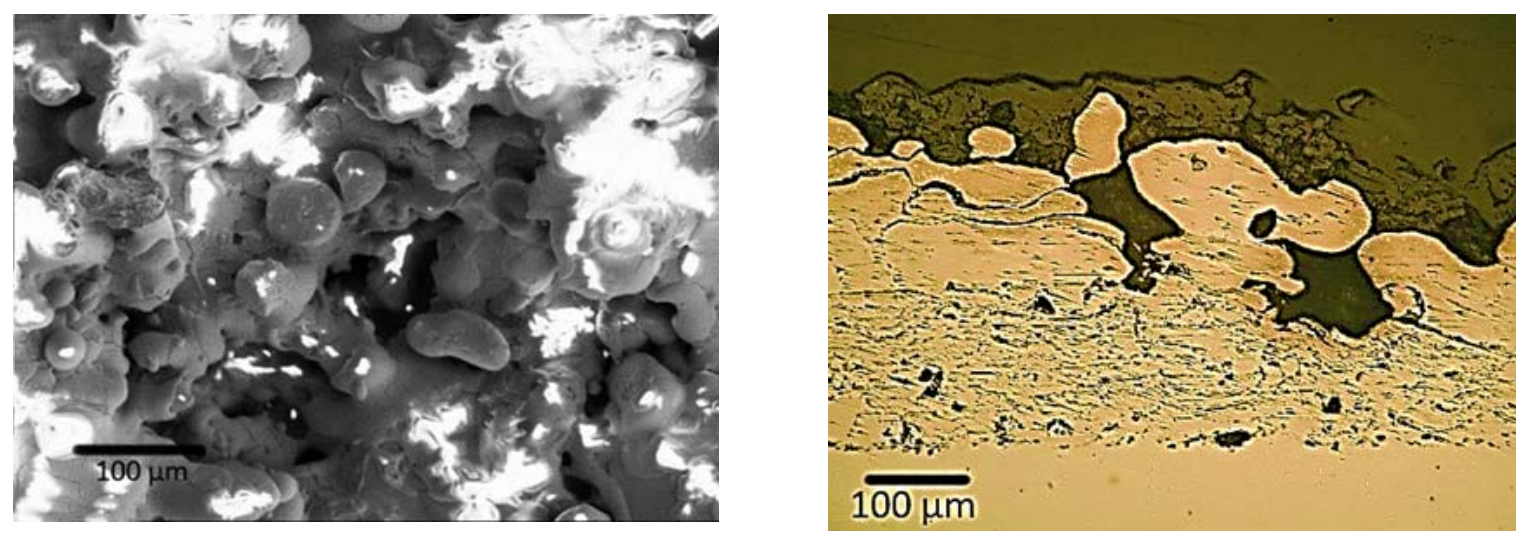

Fig. 5. The double-layer coating with the titanium lower layer and the HA upper layer: coating surface (a), cross section (b)

The desired level of porosity in the titanium lower layer (30 vol.\%) was achieved (Fig, 6a). Pore sizes in both coatings are in the range 20-100 $\mu \mathrm{m}$ (Fig.6 a,b). HA coating porosity is about $10 \%$ (Fig. 6b).

a)

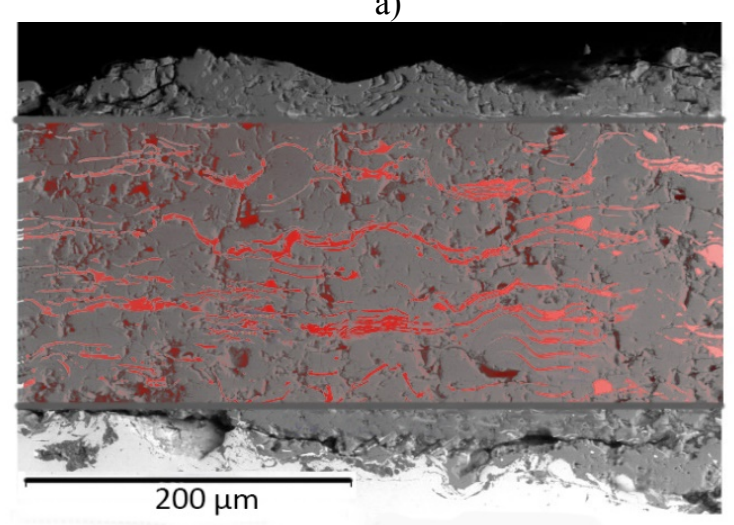

b)

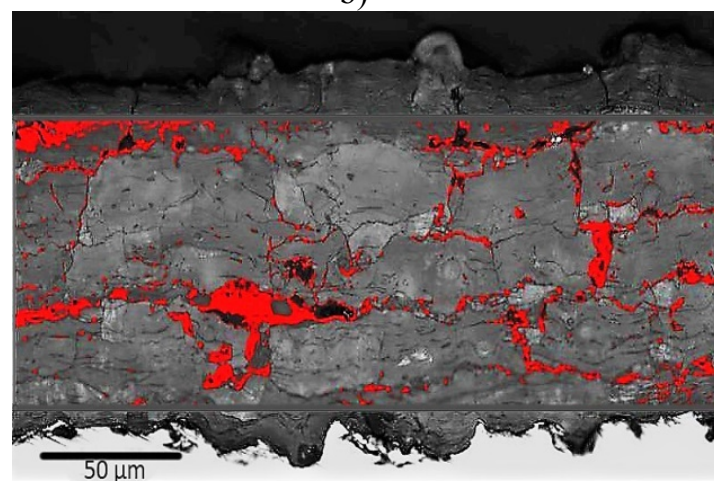

Fig. 6. The porosity test results of $\mathrm{Ti}(\mathrm{a})$ and $\mathrm{HA}(\mathrm{b})$ coatings, the red zones are the pores

Regarding the results of measuring the level of porosity in the HA coating, it should be noted that for biocompatible coatings open porosity is essential - the egress of the pore on the surface of the coating, where the bone grows. Therefore, in this case, it would be more correct to talk about the relief or morphology of the surface, perhaps by measuring the diameters of the pore craters on the surface of the coating. In our experiment, the maximum pore diameter on the surface of the HA coating was $200 \mu \mathrm{m}$ and the pores were connected to each other (Fig.5a). Thus, this study confirms that it is possible to obtain biocompatible coatings with the desired level of porosity by microplasma spraying. In order to assess the morphology and microstructure of the porous phase alternative method of observation and analysis is required. Micro-CT (micro computed tomography) observation and analysis has been used by other researchers [30, 31, 45, 46]. These methods provide the possibility of assessing the interconnectivity of the pores in a quantitative manner. They also allow more accurate assessment of the pore size and its distribution. We will be using these techniques in future to evaluate the morphologies more accurately.

It was established by XRD that the mode specified at Table 5 for HA powder provides the required structure-phase composition in the HA coating: $93 \%$ by weight of the crystalline phase, $5 \%$ by weight of $\beta$-tricalcium phosphate $(\beta$-TCP) phase and $2 \%$ by weight of the amorphous phase. Areas of existence of the amorphous HA have been found on the X-ray diffraction patterns between 28.9 and $34.22 \theta\left(^{\circ}\right)$. The peaks in the X-ray diffraction patterns 
match the standard diffraction pattern for HA (JCPDS 9-432), which provides evidence that the analysed coating is in the HA zone. All the diffraction patterns in the range of $37.32 \theta\left({ }^{\circ}\right)$ were thoroughly investigated, but even weak peaks of Calcium oxide $(\mathrm{CaO})$ were not found. So, the coating consists of $95 \%$ HA phase. This confirms that the purity meets the requirements of ISO 13779-2:2000 [26]; no harmful $\mathrm{CaO}$ compound is formed through the MPS coating of HA powder. In fact, phases such as $\beta$-phase of tetracalcium phosphate (TFA) and amorphous HA (resulted from plasma spraying) dissolve in the environment of a living organism [27-29]. These phases could largely impact the process of fixation of the implant and its subsequent behavior $[1,23]$. Thus, to define the influence of the main parameters of hydroxyapatite MPS process on the amount of $\beta$-TCP phase and amorphous phase in coatings, more development in the technology is required.

At this stage, no clinical tests on humans or animals have been carried out. However there are successful cases of MPS technology practices of applying biocompatible coatings to hip joint endoprostheses and technology implementation at MOTOR SICH JSC (Ukraine) [35]. As a result of experiments on porous titanium coatings application, the viability of microplasma wire spraying method for applying such coatings is demonstrated. Mastering new technologies for MPS of biocompatible coatings in the Republic of Kazakhstan will allow developing technologies for the production of various types of high-quality and affordable medical implants (endoprostheses, intervertebral cages, etc.) made from the domestic materials, particularly of titanium alloy ELI Grade 5 produced by the Kazakhstani Company UK TMP JSC.

\section{CONCLUSIONS}

In the course of the research, the following results were obtained:

- The influence of the synthesis time, $\mathrm{pH}$ of the medium, synthesis temperature, concentration of calcium nitrate and ammonium hydrophosphate was studied.

- The optimal parameters of synthesis of the hydroxyapatite sample were determined by the method of probabilistic-deterministic planning of the experiment: synthesis time -60 min, aging time $-16 \mathrm{~h}, \mathrm{pH} 9$, synthesis temperature $-50{ }^{\circ} \mathrm{C}$, concentration of calcium nitrate $-1 \mathrm{~mol} / \mathrm{L}$, concentration of ammonium hydrophosphate $-0.6 \mathrm{~mol} / \mathrm{L}$; aging was accompanied by ultrasonic treatment and followed by calcination at the temperature of $800^{\circ} \mathrm{C}$.

- The derived mathematical models of the process allowed calculating the conditions for carrying out the synthesis by changing at least one of the variable factors in the studied ranges in order to obtain hydroxyapatite with a given stoichiometric composition, particle size, and solubility.

- The composition and modes of microplasma deposition of two-layer coatings for titanium implants, including a sub-layer of a porous titanium coating with a thickness in range from 200 up to $300 \mu \mathrm{m}$ with a pore size of varying from 20 to $100 \mu \mathrm{m}$, and an upper layer of hydroxyapatite with a thickness of up to $100 \mu \mathrm{m}$ with with $95 \%$ level of HA phases and 93\% level of crystallinity are developed.

The results of the research are of significance for a wide range of researchers developing the technologies of biocompatible coatings manufacturing.

\section{ACKNOWLEDGEMENTS}


The study has been conducted with financial support of the Science Committee of the Ministry of Education and Science of the Republic of Kazakhstan within the framework of program-targeted financing for 2017-2019 years on the scientific and technical sub-program 0006 / PCF-17 "Manufacture of titanium products for further use in medicine".

\section{REFERENCES}

1. Tobin E.J.: Recent coating developments for combination devices in orthopedic and dental applications. A literature review. Advanced Drug Delivery Reviews 112 (2017) 88-100.

2. Goodman S.B., Yao Z., Keeney M., Yang F.: The future of biologic coatings for orthopaedic implants. Biomaterials 34 (2013) 3174-3183.

3. Heimann Robert B.: Materials Science of Bioceramic Coatings. The Open Biomedical Engineering Journal 9 (2015) 25-28.

4. Sakka S., Bouaziz J., Ayed F.B.: [In] Advances in Biomaterials Science and Biomedical Applications, R. Pignatello [ed.], InTech, London, UK, 2013, pp. 23-50.

5. Rahbek O., Overgaard S., Lind M., Bendix K., Bunger C., Soballe K.: Sealing effect of hydroxyapatite coating on peri-implant migration of particles. An experimental study in dogs. J Bone Joint Surg Br. [ed.], 2001, 83, 441-7.

6. Geesink RG.: Osteoconductive coatings for total joint arthroplasty. Clin Orthop Relat Res. [ed.], 2002, 395, 53-65.

7. Waheed S., Sultan M., Jamil T., Hussain T.: Comparative analysis of hydroxyapatite synthesized by sol-gel, ultrasonication and microwave assisted technique. Journal home page for Materials Today: Proceedings 2 (2015) 5477-5484.

8. Szcześ A., Hołysz L., Chibowski E.: Synthesis of hydroxyapatite for biomedical applications. Advances in Colloid and Interface Science 249 (2017) 321-330.

9. Fihri A., Len C., Varmac R.S., Solhy A.: Hydroxyapatite: A review of syntheses, structure and applications in heterogeneous catalysis. Coordination Chemistry Reviews 347 (2017) 48-76.

10. Geesink R. G. T.: Hydroxylapatite coatings in orthopedic surgery, R. G. T. Geesink, M. T. Manicy [ed.], Raven Press, Ltd. New York, 1993, pp. 1-319.

11. Betke A., Kickelbick G.: Bottom-Up, wet chemical technique for the continuous synthesis of inorganic nanoparticles. Inorganics 2 (2014) 1-15.

12. Vilardell A.M., Cinca N., Garcia-Giralt N., Dosta S., Cano I.G., Nogués X., Guilemany J.M.: Functionalized coatings by cold spray: An in vitro study of micro- and nanocrystalline hydroxyapatite compared to porous titanium. Materials Science and Engineering 87 (2018) 41-49.

13. Farrokhi-Rad M.: Electrophoretic deposition of hydroxyapatite fiber reinforced hydroxyapatite matrix nanocomposite coatings. Surface and Coatings Technology 329 (2017) 155-162.

14. Adeleke S.A., Ramesh S., Bushroa A.R., Ching Y.C., Sopyan I., Maleque M.A., Krishnasamy S., Chandran H., Misran H., Sutharsini U.: The properties of hydroxyapatite ceramic coatings produced by plasma electrolytic oxidation. Ceramics International 44 (2018) 1802-1811.

15. Ivanova A.A., Surmeneva M.A., Tyurin A.I., Surmenev R.A.: Correlation between structural and mechanical properties of RF magnetron sputter deposited hydroxyapatite coating. Materials Characterization 142 (2018) 261-269.

16. Trommer R.M., Santos L.A., Bergmann C.P.: Alternative technique for hydroxyapatite coatings. Surface and Coatings Technology 201 (2007) 9587-9593. 
17. Liu Y.-C., Lin G.S., Wang J.-Y., Cheng C.-S., Yang Y.-C., Lee B.-S., Tung K.-L.: Synthesis and characterization of porous hydroxyapatite coatings deposited on titanium by flame spraying. Surface and Coatings Technology 349 (2018) 357-363.

18. Hidalgo-Robatto B.M., López-Álvarez M., Azevedo A.S., Dorado J., Serra J., Azevedo N.F., González P.: Pulsed laser deposition of copper and zinc doped hydroxyapatite coatings for biomedical applications. Surface and Coatings Technology 333 (2018) 168-177.

19. Domínguez-Trujillo C., Peón E., Chicardi E., Pérez H., Rodríguez-Ortiz J.A., Pavón J.J., García-Couce J., Galván J.C., García-Moreno F., Torres Y.: Sol-gel deposition of hydroxyapatite coatings on porous titanium for biomedical applications. Surface and Coatings Technology 333 (2018) 158-162.

20. Xu H., Geng X., Liu G., Xiao J., Li D., Zhang Y., Zhu P., Zhang C.: Deposition, nanostructure and phase composition of suspension plasma-sprayed hydroxyapatite coatings. Ceramics International 42 (2016) 8684-8690.

21. Matassi F., Botti A., Sirleo L., Carulli C., Innocenti M.: Porous metal for orthopedics implants Clin. Cases Miner. Bone Metab. 10(2) (2013) 111-115 PMID: 24133527.

22. Yang C.Y., Wang B.C., Chang E., Wu B.C.: The influences of plasma spraying parameters on the characteristics of hydroxyapatite coatings: a quantitative study. J. of Materials Sci.: Materials in Medicine 6 (1995) 249-257.

23. Heimann R.B.: Thermal spraying of biomaterials, Surface and Coatings Technology. 201 (2006) 2012-2019.

24. Sridhar T.M., Kamachi U. and Subbaiyan M.: Sintering atmosphere and temperature effects on hydroxyapatite coated type 316L stainless steel. Corros. Sci. 45 (2008) 2337-2359.

25. Yang Y., Kim K., Agrawal C. M. and Ong J. L.: Interaction of hydroxyapatite-titanium at elevated temperature in vacuum environment. Biomaterials. 25 (2004) 2927-2932.

26. Implants for Surgery- Hydroxyapatite. Part 2: Coatings of Hydroxyapatite. International Organisation for Standards. BS ISO 13779-2:2000, 2000.

27. Vahabzadeh S., Roy M., Bandyopadhyay A., Bose S.: Phase stability and biological property evaluation of plasma sprayed hydroxyapatite coatings for orthopedic and dental applications. Acta Biomaterialia 17 (2015) 47-55.

28. Overgaard S, Bromose U, Lind M, Bunger C, Soballe K.: The influence of crystallinity of the hydroxyapatite coating on the fixation of implants. Mechanical and histomorphometric results, $\mathrm{J}$ Bone Joint Surg Br. 1999, 81, 725-31.

29. Sun L, Berndt CC, Khor KA, Cheang HN, Gross KA.: Surface characteristics and dissolution behavior of plasma-sprayed hydroxyapatite coating. J Biomed Mater Res. 62(2) (2002) 228-36.

30. Rouholamin D., Smith P. J., Ghassemieh E.: Control of morphological properties of porous biodegradable scaffolds processed by supercritical $\mathrm{CO}_{2}$ foaming. J Mater Sci 48 (2015) 32543263 .

31. Wiria F.E., Tay B.Y., Ghassemieh E.: Morphological and cell growth assessment in near dense hydroxyapatite scaffold. Journal of Materials ID 287853 (2013).

32. Latka L., Pawlowski L., Chicot D., Pierlot C., Petit F.: Mechanical properties of suspension plasma sprayed hydroxyapatite coatings submitted to simulated body fluid. Surface and Coatings Technology 205 (2010) 954-960.

33. Yushenko K., Borisov Yu., Voynarovych S., Fomakin O.: Plasmatron for spraying of coatings/ Pub. No.: WO/2004/010747 International Application. No.: PCT/UA2003/000014 Publication Date: 29.01.2004; International Filing Date: 25.04.2003, IPC: H05H 1/32. - 2006.

34. Borisov Yu.S., Voinarovych S.G., Kyslytsia A.N., Borisova A.L., Tunik A. Yu.: Effect of 
microplasma spray conditions on structure, phase composition and texture of hydroxyapatite coatings. Proc. of the Int. Thermal Spray Conference and Exposition ITSC 2006, Building on 100 Years of Success, Seattle, Washington, USA (2006) 29-34.

35. Yuschenko K.A., Borisov Yu.S., Borisova A.L., Voinarovych S.G., Kyslytsia A.N., Tunik A. Yu., Adeeva L.I., Kuzmich- Yanchuk E.K.: Mikroplazmennoye provolochnoye napyleniye biomeditsinskikh titanovykh pokrytiy. Poroshkovaya metallurgiya. Sbornik nauchnykh trudov. Minsk: izdatelstvo «Belaruskaya navuka» Is.36 (2013) 261-268.

36. Yushchenko K.A., Borisov Yu.S., Voinarovych S.G, Kyslytsia O. N., Kuzmich-Yanchuk Ye.K., Gaiko G.V., Pidgaetsky V. M.: Dvukhsloynoye biokermetnoye pokrytiye titan-gidroksiapatit. Problemi resursu bezpekiyekspluatatsii konstruktsiy, sporudta mashin. Sbornik trudov posvyashchennyy vypolneniyu kompleksnoy programmy. Kiev (2009) 542-547.

37. Voinarovych S.G.: Vliyaniye parametrov mikroplazmennogo napyleniya na koeffitsiyent ispolzovaniya materiala pri napylenii biokeramicheskogo pokrytiya. Obrobka Materialiv u Mashinobuduvanni (2010) 58-61.

38. Thirumalaikumarasamya D., Shanmugama K., Balasubramanian V.: Influences of atmospheric plasma spraying parameters on the porosity level of alumina coating on AZ31B magnesium alloy using response surface methodology. Progress in Natural Science: Materials International 22(5) (2012) 468-479.

39. Mohseni E., Zalnezhad E., Bushroa A.R.: Comparative investigation on the adhesion of hydroxyapatite coating on Ti-6Al-4V implant: A review paper. International Journal of Adhesion and Adhesives 48 (2014) 238-257.

40. Alontseva D.L., Borisov Yu. S., Voinarovych S.G., Kyslytsia O. N., Kolesnikova T.A., Prokhorenkova N.V., Kadyroldina A.T.: Development of technology of microplasma spraying for the application of biocompatible coatings in the manufacture of medical implants. Przegląd Elektrotechniczny 94 (7) (2018) 94-97.

41. Alontseva D.L., Voinarovych S.G., Kyslytsia O. N., Dzhes A.V., Russakova A.V., Prokhorenkova N.V., Krasavin A.L., Leonova M.O.: Structural-phase transformations in coatings from biocompatible materials applied by microplasma spraying onto titanium implants. Basic Problems of Material Science 15 (1) (2018) 126-132.

42. Sobczak A., Kowalski Z., Wzorek Z.: Preparation of hydroxyapatite from animal bones. Acta of Bioengineering and Biomechanics 11(4) (2009) 23-28.

43. ASTM E2109-01(2014) Standard test methods for determining area percentage porosity in thermal sprayed coatings, ASTM International, West Conshohocken, PA, 2014

44. Abilev M.B, Troyeglazova A.V., Akatan K., Alontseva D.L.: Mathematical modeling of the process of hydroxyapatite synthesis. Proc. 8-th Int. Conf. on Chemistry and Chemical Education Research Institute for Physical Chemical Problems of the Belarusian State University, Minsk, Belarus, 2018, p. 25.

45. Gagg G., Ghassemieh E., Wiria F.E.: Effects of sintering temperature on morphology and mechanical characteristics of 3D printed porous titanium used as dental implant Materials. Science \& Engineering C. Materials for Biological Applications 33(7) (2013) 3858-3864.

46. Gagg G., Ghassemieh E., Wiria F.E.: Analysis of the compressive behavior of the threedimensional printed porous titanium for dental implants using a modified cellular solid model. Proc IMechE Part H: J Engineering in Medicine 0(0) (2013) 1-7. 